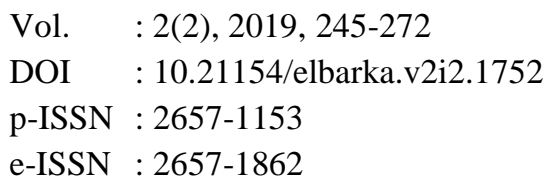

\title{
PERSEPSI AKUNTAN MANAJEMEN TERHADAP PENERAPAN TAX PLANNING
}

\author{
Renil Septiano \\ Sekolah Tinggi Ilmu Ekonomi KBP \\ renil.septiano@akbpstie.ac.id \\ Nila Sari \\ Sekolah Tinggi Ilmu Ekonomi KBP \\ nilasari@akbpstie.ac.id
}

\begin{abstract}
Tax planning is a means of fulfilling tax obligations well but the amount of tax paid can be reduced as low as possible to obtain the expected profit and liquidity. This study aims to see the effect of management accountants' perceptions on the implementation of tax planning. The type of research used is quantitative, using primary data. The population of the research was in Food Distributor companies in the Padang City. Respondents who were taken were employees who served as part of accounting staff, management and financial staff companies who worked at the Food Distributor Padang City. Selection of samples was selected using the Convenience sampling method with 30 respondents. Technical data analysis using simple regression analysis. The test results show that the perception variables of management accountants with a significant value of 0,000 <0,05. Based on the test results it was found that the perception of management accountants has an effect on the implementation of tax planning
\end{abstract}

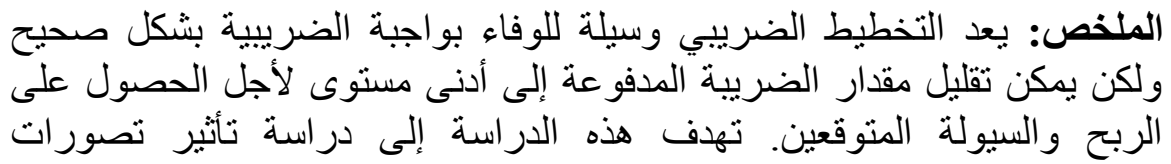


المحاسبين الإداريين على تطبيق التخطيط الضريبي. نوع البحث المستخدم كمي،

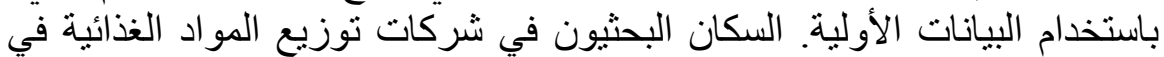

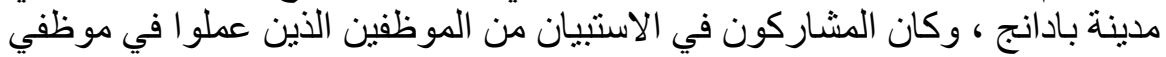

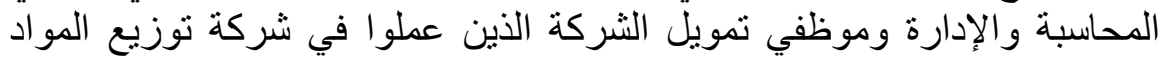

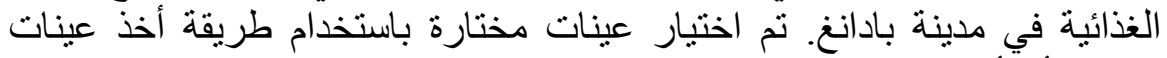

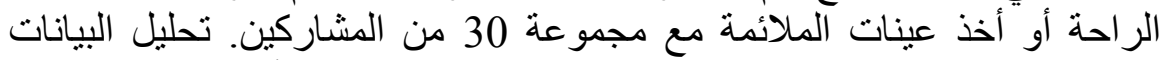

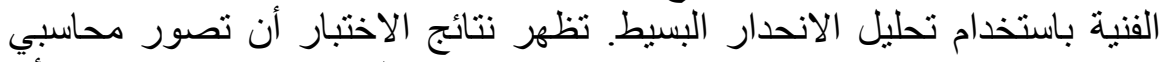

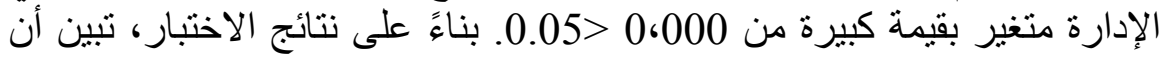
تصور محاسبي الإدارة يؤثر على تطبيق التخطيط الضريبي.

Abstrak: Tax planning merupakan sarana dalam memenuhi kewajiban perpajakan dengan baik tetapi jumlah pajak yang dibayar dapat ditekan serendah mungkin untuk memperoleh laba dan likuiditas yang diharapkan. Penelitian ini bertujuan untuk melihat pengaruh persepsi akuntan manajemen terhadap penerapan tax planning. Jenis penelitian yang digunakan bersifat kuantitatif, dengan menggunakan data primer. Populasi penelitian pada perusahaan Distributor Makanan di Kota Padang, Responden yang diambil adalah pegawai yang menjabat dibagian staff akuntasi, menejemen dan staff keuangan perusahaan yang bekerja pada perusahaan Distributor Makanan Kota Padang. Pemlihan sampel dipilih menggunakan metode Convenience sampling atau sampling kemudahan dengan jumlah 30 orang responden. Teknis analisis data menggunakan analisis regresi sederhana. Hasil pengujian menunjukkan bahwa variabel persepsi akuntan manajemen dengan nilai signifikan $0,000<0,05$. Berdasarkan hasil pengujian didapat bahwa persepsi akuntan manajemen berpengaruh terhadap penerapan tax planning

Keywords: Persepsi Akuntan Manajemen, Penerapan tax planning

\section{PENDAHULUAN}

Pajak merupakan salah satu penerimaan suatu Negara yang utama di Indonesia dan besar selain Minyak Bumi dan Gas Alam yang sangat 
penting peranannya untuk keberlangsungan hidup masyarakat Indonesia. Pajak menurut Waluyo menyebutkan bahwa iuran kepada suatu Negara (yang dapat dipaksakan) yang terutang oleh yang wajib membayarnya menurut peraturan-peraturan yang berlaku dengan tidak mendapat prestasi kembali, yang langsung dapat ditunjuk yang dengan tugas Negara untuk menyelenggrakan pemerintahan.

Pajak bagi sebagian besar Negara di Dunia digunakan sebagai sumber penerimaan utama Negara, termasuk Indonesia, wajar saja bila pemerintah terus berupaya untuk melakukan pemungutan pajak hingga mencapai tingkat penerimaan yang sangat optimal agar penerimaan kas negara menjadi stabil dan pembangunan negara dapat berjalan dengan baik. Keberlangsungan pemungutan Pajak di Indonesia diharapkan akan selalu meningkat seiring dengan perkembangan dan kemajuan teknologi yang pesat mendorong peningkatan dalam penerimaan pajak. Pemerintah dalam menjalankan pemerintahan membutuhkan dana yang tidak sedikit dalam menjalankan pemerintahan dan pembangunan. Iuran dana dari masyarakat yang diberdayakan dan dikumpulkan berasal Pajak Penghasilan (PPh), Pajak Pertambahan Nilai (PPN), Pajak Penjualan atas Barang Mewah (PPn BM), Bea Meterai, Pajak Bumi dan Bangunan (PBB), Bea Perolehan Hak Atas Tanah dan Bangunan (BPHTB $)^{1}$. Dana yang didapat dialokasikan untuk kepentingan masyarakat. Pemungutan pajak yang dilakukan Empat, 34

1 Waluyo. (2017). Perpajakan Indonesia (12th ed.). Jakarta: Salemba 
pemerintah mengeluarkan kebijakan-kebijakan yang berhubungan dengan perpajakan dengan tetap memperhatikan asas keadilan, kepastian, dan kenyamanan ${ }^{2}$.

Pemungutan pajak kepada perusahaan atas pajak badan yang telah diatur oleh undang-undang no 36 tahun 2008 terhadap besarnya tarif pajak penghasilan perusahaan berdasarkan kategori laba perusahaan. Peraturan Undang-undang tersebut yang telah ditetapkan menerapkan sistem self-assessment sebagai pemungutan pajak dimana wajib pajak diwajibkan mendaftar, menghitung, membayar, dan melaporkan sendiri jumlah pajak yang terutang ${ }^{3}$

Ketentuan pajak yang telah ditetapkan didalam undangundang sangat berpengaruh terhadap dunia usaha, hal tersebut meningkatkan kompetisi dan prestasi suatu badan usaha dimana kegiatan usahanya melakukan upaya meningkatkan tujuan perusahaan yaitu mendapatkan laba dan mengurangi menimalisir beban pajak yang dikeluarkan perusahaan ${ }^{4}$. Bagi perusahaan pajak yang dikenakan kepada perusahaan terhadap penghasilan perusahaan dianggap sebagai biaya dalam menjalankan atau melakukan kegiatan

2 Annisa, R. R., \& Handayani, B. D. (2015). Analisa Faktor Yang Memotivasi Manajemen Perusahaan Melakukan Tax Planning. Accounting Analysis Journal, 4(1), 1-11. 8

${ }^{3}$ Mardiasmo. (2009). Perpajakan Edisi Revisi. Yogyakrta: Andi., 53

${ }^{4}$ Rori, H. (2013). Analisis Penerapan Tax Planning Atas Pajak Penghasilan Badan. Jurnal EMBA, 1(3), 410-418, 413 
usaha, besarnya pajak penghasilan yang dikeluarkan berpengaruh pada berkurangnya laba perusahaan. ${ }^{5}$

Pengeluaran pajak yang dilakukan perusahaan untuk pembangunan nasional suatu Negara dipengaruhi besarnya pajak suatu negara. Bagi perusahaan besarnya pengeluaran pajak tergantung besar kecil laba perusahaan, semakin besar laba perusahaan maka semakin besar kewajiban pajak yang dikeluarkan perusahaan kepada pemerintah. Pengeluaran pajak yang dikeluarkan perusahaan dalam jumlah besar yang ingin diminimalisir, agar pengeluaran pajak menjadi kecil. Menimalisir biaya pajak dapat dilakukan berbagai cara, ada yang melakukan dengan cara yang sesuai undang-undang, bahkan sampai melakukan pelanggaran perpajakan. Faktor pemicu inilah muncul istilah Tax Planning. Tax planning adalah proses mengorganisasi usaha wajib pajak atau kelompok wajib pajak sedemikian rupa sehingga utang pajaknya, baik pajak penghasil maupun pajak lainnya, berada dalam posisi yang paling minimal. ${ }^{6}$

Tax Planning merupakan salah satu upaya dalam penghematan pajak secara legal. Tax planning merupakan sarana dalam memenuhi kewajiban perpajakan dengan baik tetapi jumlah pajak yang dibayar dapat ditekan serendah mungkin untuk memperoleh laba dan likuiditas yang diharapkan. Setiap wajib pajak

\footnotetext{
${ }^{5}$ Natakharisma, V., \& Sumadi, I. K. (2014). Analisis Tax Planning Dalam Meningkatkan Optimalisasi Pembayaran Pajak Penghasilan Pada PT . Chidehafu. E-Jurnal Akuntansi Universitas Udayana, 2, 324-339, 330

6 Indrawati, \& Budiwitaksono, G. S. (2017). Studi Faktor-Faktor Pemotivasi Manajemen Melakukan Tax Planning. Jurnal Akuntansi, 19(3), 370
} 
memiliki peluang yang sama dalam melakukan tax planning untuk menimalkan penghasilan kena pajak. Tax Planning pada dasarnya suatu usaha dalam penghematan pajak berdasarkan the least and latest rule yaitu wajib pajak berusaha menekan pajak sekecil mungkin dan menunda pembayaran selambat mungkin sebatas masih diperkenankan didalam perundang-undangan perpajakan berlak. ${ }^{7}$ Penerapan Tax Planning dipengaruhi oleh persepsi akuntan manajemen.

Persepsi merupakan proses memahami lingkungan meliputi objek, orang, dan simbol atau tanda yang melibatkan proses kognitif Gibson, Ivancevich, Jr.Donnelly, \& Konopaske (2011), Robbins \& Judge (2008). Persepsi mencakup penerimaan, pengorganisasian dan penafsiran stimulus yang telah diorganisir dengan cara yang dipengaruhi perilaku dan membentuk sikap Martadi \& Suranta, (2006) dan Robbins \& Judge (2008). Akuntan manajemen merupakan suatu peran kunci dalam bidang keuangan, dengan berbagai posisi yang ada di sektor praktik umum, korporasi dan sektor publik, jasa keuangan, dan organisasi layanan bersama (shared service organisations) ${ }^{8}$. Seorang Akuntan manejer berperan penting dalam setiap pengambilan keputusan didalam perusahaan. Persepsi seorang akuntan manajemen dalam setiap mengambil keputusan menentukan kebijakan dan analis untuk

7 Muhammadinah. (2015). Penerapan Tax Planning Dalam Upaya Meningkatkan Efisiensi Pembayaran Beban Pajak Pada Cv. Iqbal Perkasa. I-Finance, 1(1), 21-34, 27

${ }^{8}$ Sucipto. (2004). Penerapan Akuntansi Manajemen Dalam Mengambil Keputusan. Jurnal Universitas Sumatera Utara, 1-8, 4. 
keberlangsungan hidup perusahaan ${ }^{9}$. Informasi yang digunakan seorang akuntan manajemen sebagai dasar pengambilan keputusan adalah informasi yang utama dan relevan, informasi tersebut digunakan didalam menunjang pelanksanaan fungsi manajemen khususnya fungsi perencanaan dan pengawasan.

Penelitian yang dilakukan Tanjung \& Tjondro (2013), Muhammadinah, (2015), Indrawati \& Budiwitaksono (2017) persepsi akuntan manajemen berpengaruh terhadap Tax Planning. Semakin baik Seorang akuntan manajemen dalam memberikan pandangan dan keputusan maka akan semakin baik penerapan tax planning. Penggunaan informasi dan kebijakan dalam menentukan metode tax planning didalam perusahaan akan memberikan penghematan pajak didalam perusahaan. Penerapan tax planning didalam perusahaan memberikan effisiensi pembayaran beban pajak didalam perusahaan. Penghematan dalam membayar pajak ditakan effektif dan effisien apabila menggunakan tax planning menggunakan metode yang tepat dan sesuai dengan undang-undang perpajakan yang berlaku. Penguasaan seorang manajemen dalam memahami peraturan dan perudang-undangan perpajakan yang berlaku maka pihak manajemen perusahaan dapat menjalankan kebijakan tax planning yang dibuat tanpa melanggar peraturan perudang-undangan perpajakan (Harahap, 2009).

${ }^{9}$ Rusmanto, Mentayani, I., \& Yani, S. N. (2014). Persepsi Akuntan dan Mahasiswa Jurusan Akuntansi Terhadap Kode Etik Ikatan Akuntan Indonesia. JAFFA, 2(2), 115-126, 118 
Berdasarkan teori dan hasil-hasil penelitian terdahulu maka dapat diturunkan hipotesis yang dapat dibuktikan secara empiris: (H1) Persepsi Akuntan Manajemen berpengaruh terhadap Penerapan Tax Planning.

\section{METODOLOGI PENELITIAN}

Data yang digunakan di dalam penelitian ini adalah data Primer yaitu data yang diperoleh dari hasil analisis data kuisioner responden. Pengumpulan data langsung observasi kelapangan.

Populasi dalam penelitian ini adalah Distributor makanan yakninya di Kota Padang. Responden yang diambil adalah pegawai yang menjabat dibagian staff akuntasi, menejemen perusahaan dan staff keuangan yang bekerja di Distributor Makanan Kota Padang. Pemilihan sampel dilakukan dengan menggunakan metode Convenience sampling atau sampling kemudahan, juga disebut sebagai sampling kebetulan atau sampling aksidental, atau sampling sembarang merupakan sampling dari siapa saja yang kebetulan ada dijumpai atau tersedia menurut keinginan peneliti ${ }^{10}$. Sampel yang diambil adalah pegawai yang menjabat dibagian staf akuntasi, menejemen perusahaan dan staff keuangan yang bekerja di Distributor Makanan Kota Padang. Jumlah perusahaan yang dapat menjadi sampel sebanyak 6 perusahaan dengan jumlah responden 30 responden

\footnotetext{
${ }^{10}$ Sugiyono. (2017). Metode Penelitian Bisnis. Bandung: Alfabeta, 48
} 
Penelitian menggunakan teknik kuesioner dalam mengumpulkan data yang dibutuhkan. Kuisioner yang diberikan kepada respoden berupa pertanyaan yang telah disusun sesuai dengan item variabel penelitian yang digunakan. Data yang dikumpulkan berasal dari responden staff perusahaan distributor makanan di Kota Padang.

Defnisi operasional penelitian disajikan dalam tabel di bawah ini:

\section{Tabel 1}

\section{Definisi Operasional Variabel}

\begin{tabular}{|c|c|c|c|}
\hline No & Variabel & Definisi Opersional & Indikator \\
\hline 1 & $\begin{array}{l}\text { Persepsi } \\
\text { akuntan } \\
\text { Manajemen }\end{array}$ & $\begin{array}{l}\text { Persepsi juga didefenisikan } \\
\text { sebagai proses dimana individu } \\
\text { mengatur } \\
\text { menginterprestasikan kesan-kesan } \\
\text { sensoris merekar guna } \\
\text { memberikan arti bagi lingkungan } \\
\text { mereka. Namun, apa yang } \\
\text { diterima seseorang pada dasarnya } \\
\text { bisa berbeda dari realitas objektif } \\
\text { (Rusmanto et al., 2014) Akuntan } \\
\text { merupakan proses dalam } \\
\text { membuat suatu perencanaan, } \\
\text { pengorganisisasian, pengendalian } \\
\text { serta memimpin berbagai usaha } \\
\text { dari anggota entitas/organisasi }\end{array}$ & $\begin{array}{l}\text { 1.Kepentingan } \\
\text { Manajemen } \\
\text { 2.Transparasi }\end{array}$ \\
\hline
\end{tabular}




\begin{tabular}{|c|c|c|c|}
\hline & Variabel & Definisi Opersional & Indikator \\
\hline & & $\begin{array}{l}\text { dan juga mempergunakan semua } \\
\text { sumber daya yang dimiliki untuk } \\
\text { mencapai tujuan yang ditetapkan }\end{array}$ & \\
\hline 2 & $\begin{array}{l}\text { Penerapan } \\
\text { tax planing }\end{array}$ & 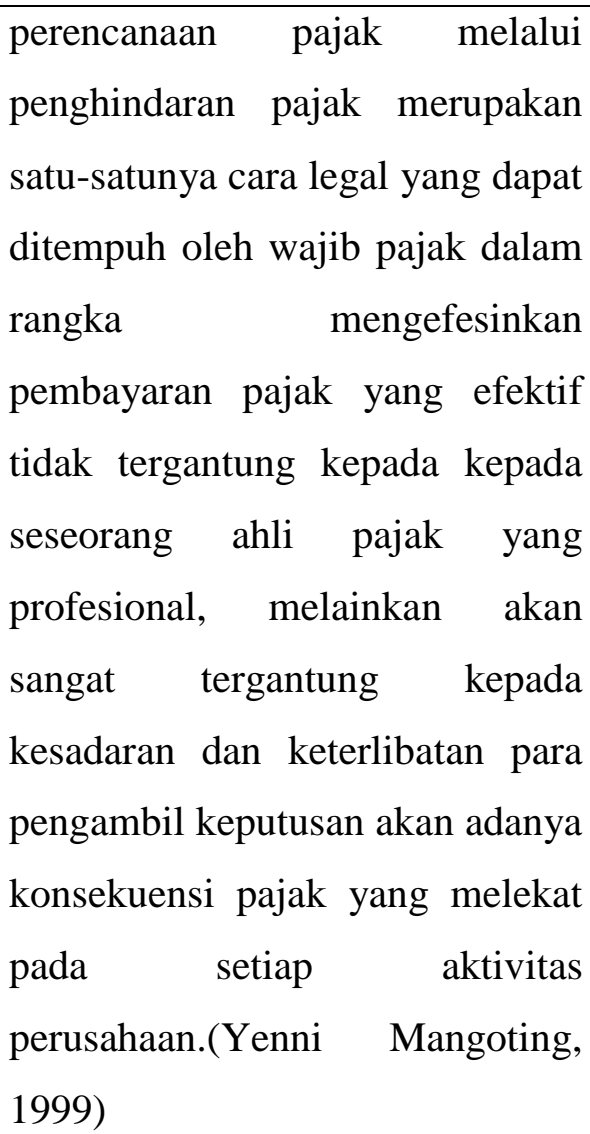 & Perencanaan Pajak \\
\hline
\end{tabular}


Tabel 2

Instrumen Penelitian

\begin{tabular}{|c|c|c|c|}
\hline No & Variabel & Indikator & Kuisioner \\
\hline \multirow[t]{2}{*}{1} & \multirow[t]{2}{*}{$\begin{array}{l}\text { Persepsi } \\
\text { Akuntan } \\
\text { Manajemen }\end{array}$} & $\begin{array}{l}\text { a. Kepentingan } \\
\text { Manajemen }\end{array}$ & $\begin{array}{l}\text { 1. Akuntan berkewajiban untuk } \\
\text { senantiasa bertindak dalam } \\
\text { kerangka pelayanan publik } \\
\text { secara profesional } \\
\text { 2. Akuntan manajemen tidak } \\
\text { wajib mengikuti standar profesi } \\
\text { yang dititikberakan pada } \\
\text { kepentingan manajemen } \\
\text { 3. Akuntan manajemen } \\
\text { bertanggung jawab kepada } \\
\text { pemilik } \\
\text { 4. Akuntan Manjemen diharuskan } \\
\text { untuk mengumpulkan dan } \\
\text { memberikan informasi } \\
\text { 5. Akuntan manajemen berfokus } \\
\text { pada informasi akuntansi yang } \\
\text { sesuai dengan pembuatan dan } \\
\text { perencaaan dan pengambilan } \\
\text { kenutucan }\end{array}$ \\
\hline & & b. Transparasi & $\begin{array}{l}\text { 1. Akuntan manajemen } \\
\text { berkewajiban melaporkan } \\
\text { setiap bentuk tindakan yang } \\
\text { merugikan perusahaan } \\
\text { 2. Akuntan manajemen berperan } \\
\text { aktif dalam siklus perencanaan } \\
\text { dan pengendalian laba } \\
\text { 3. Perusahaan menyajikan laporan } \\
\text { keuangan seperti kas, laporan } \\
\text { laba rugi, laporan neraca secara } \\
\text { transparan } \\
\text { 4. Perusahaan mengumumkan } \\
\text { informasi tentang kerjasama } \\
\text { dengan perusahaan lain }\end{array}$ \\
\hline
\end{tabular}




\begin{tabular}{|c|c|c|c|}
\hline & & & $\begin{array}{l}\text { 5. Perusahaan menyampaikan } \\
\text { informasi dengan jelas }\end{array}$ \\
\hline 2 & $\begin{array}{ll}\text { Tax } & \text { Planing } \\
(\mathrm{Y}) & \end{array}$ & $\begin{array}{l}\text { Perencanaan } \\
\text { Pajak }\end{array}$ & 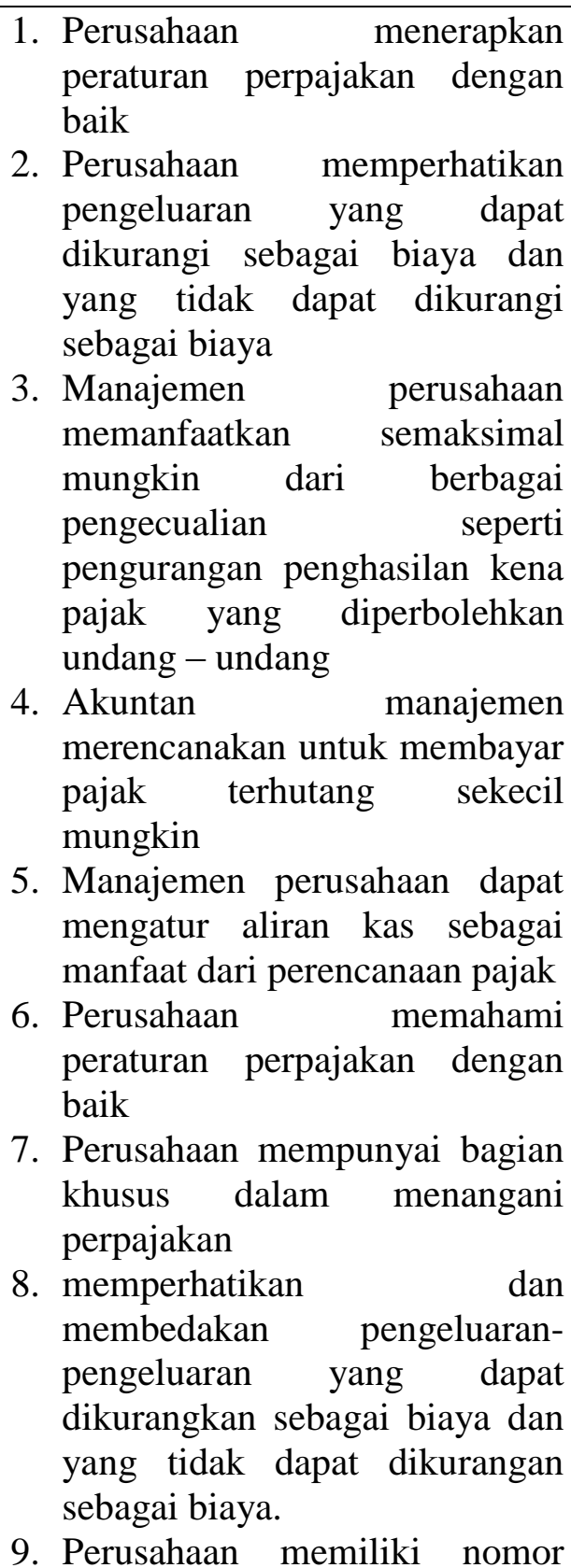 \\
\hline
\end{tabular}




\begin{tabular}{|l|l|l|}
\hline & & pokok wajib pajak \\
& & $\begin{array}{l}\text { 10. Manajemen Perusahaan dapat } \\
\text { mengatur aliran kas dengan } \\
\text { baik sebagai manfaat dari } \\
\text { perencanaan pajak }\end{array}$ \\
\hline
\end{tabular}

Pengolahan data dalam penelitian dilakukan dengan menggunakan bantuan program SPSS 23 dengan melakukan analisis menggunakan model regresi analisis sederhana. Model regresi sederhana yang digunakan dirumuskan kedalam persamaan dibawah ini

$$
\mathrm{PTP}=\beta_{0}+\beta_{1} P A K_{i t}+e
$$

Berdasarkan model regresi sederhana menjelaskan bahwa TP merupakan Penerapan Tax Planning, PAK merupakan Persepsi Akuntan Manajemen, $a$ dan $\beta_{0}$ merupakan Konstanta, $\beta_{1}$ merupakan Koefisien regresi dan terakhir e merupakan error.

Pengujian Instrumen item pertanyaan kuesioner digunakan uji Validitas da reabilitas. Uji validitas digunakan untuk mengukur valid atau tidaknya suatu kuesioner. Suatu kuesioner dikatakan valid jika pertanyaan- pertanyaan yang ada dalam kuesioner tersebut mampu mengungkapkan sesuatu yang diukur oleh kuesioner tersebut. Uji validitas pada penelitian ini dilakukan dengan membandingkan nilai corrected item-total correlation dengan perhitungan $\mathrm{r}$ tabel untuk degree of freedom $(\mathrm{df})=\mathrm{n}-2$, dimana dalam hal ini $\mathrm{n}$ adalah jumlah sampel, dengan tingkat Signifikansi 5 
persen. Jika $r$ hitung lebih besar dari $r$ tabel dan bernilai positif maka butir pernyataan atau indikator tersebutdinyatakan valid.

Uji reliabilitas adalah alat untuk mengukur suatu kuesioner yang merupakan indikator dari variabel atau konstruk. Suatu kuesioner dikatakan reliabel atau handal jika jawaban seseorang terhadap pertanyaan adalah konsisten atau stabil dari waktu ke waktu .Pengujian ini dilakukan untuk menghitung koefisien Cronbach alpha dari masing-masing instrumen dalam suatu variabel.Instrumen dapat dikatakan handal (reliable) bila mempunyai koefisien Cronbach alpha $>0.60$. Hasil uji reliabilitas kuesioner sangat tergantung pada kesungguhan responden dalam menjawab semua item pernyataan penelitian ${ }^{11}$.

Pengujian Hipotesis menggunakan ujia $\mathrm{t}$ yang bertujuan untuk menunjukkan seberapa jauh pengaruh satu variabel penjelas atau independen secara individual dalam menerangkan variasi variabel independen, dengan tingkat signifikansi 5\%, maka kriteria pengujian adalah sebagai berikut: Bila nilai signifikansi $\mathrm{t}<0,05$, maka H0 ditolak, Ha diterima, artinya terdapat pengaruh yang signifikan antara satu variabel independen terhadap variabel dependen. Apabila nilai signifikansi t > 0,05, maka H0 diterima, $\mathrm{Ha}$ ditolak, artinya tidak ada pengaruh yang signifikan antara satu variabel independen terhadap variabel dependen ${ }^{12}$

11 Imam Ghazali. (2013). Analisasis Multivariat DenganPogram SPSS (dua). Semarang: Universitas diponegoro, 60

${ }^{12}$ Ibid, 62 
Nilai koefisien determinasi adalah antara nol dan satu. Nilai R2 yang kecil berarti kemampuan variabel-variabel independen dalam menjelaskan variasi variabel dependen amat terbatas. Nilai yang mendekati satu berarti variabel- variabel independen memberikan hampir semua informasi yang dibutuhkan untuk memprediksi variasi variabel dependen, semakin mendekati nilai 1 atau $100 \%$, maka semakin besar pengaruh variabel independen terhadap variabel dependen. ${ }^{13}$

\section{HASIL DAN PEMBAHASAN}

Deskripsi responden atau karakteristik responden berguna untuk menguraikan deskripsi identitas responden menurut sampel penelitian yang telah ditetapkan, salah satu tujuannya untuk memberikan gambaran objek yang menjadi sampel dalam penelitian ini. Karakteristik responden dalam sampel ini dikelompokkan menurut usia, jenis kelamin, lama jabatan dan pendidikan terakhir. Untuk memperjelas karakteristik responden ini, maka akan disajikan di dalam tabel mengenai data responden seperti yang dijelaskan berikut ini:

\section{Karakteristik Responden Berdasarkan Usia}

Berdasarkan proses tabulasi data yang telah dilakukan dapat diklasifikasikan usia responden yang berpatisipasi di dalam penelitian, seperti yang terlihat pada tabel 3 dibawah ini:

${ }^{13}$ Ibid, 64 


\section{Tabel 3}

Karakteristik Responden Berdasarkan Usia

\begin{tabular}{|c|c|c|c|}
\hline \multirow{2}{*}{ No } & \multirow{2}{*}{ Usia } & \multicolumn{2}{|c|}{ Jumlah } \\
\cline { 3 - 4 } & & Frekuensi & Persentase \\
\hline 1 & $20-30$ tahun & 25 & 83 \\
\hline 2 & $31-40$ tahun & 5 & 17 \\
\hline & Jumlah & $\mathbf{3 0}$ & $\mathbf{1 0 0 \%}$ \\
\hline
\end{tabular}

Sumber: Data Primer diolah dengan SPSS 23 (2019)

Pada tabel terlihat bahwa pada umumnya responden yang berpatisipasi di dalam penelitian ini memiliki tingkatan usia antara 20-30 tahun adalah 25 orang (83\%), dan untuk usia 31 - 40 tahun adalah 5 orang (17\%). Usia rata-rata yang paling besar berada diusia 21-30 tahun yang berjumlah sekitar 25 orang (83\%), hal ini dikarenakan dalam usia tersebut masih baru dalam melaksanakan tugasnya terutama dalam kinerja pelaporan keuangan Perusahaan Dagang Di Kota Padang.

\section{Karakteristik Responden Berdasarkan Jenis Kelamin}

Berdasarkan proses tabulasi data dapat dikelompokkan karakteristik umum responden berdasarkan jenis kelamin seperti terlihat pada tabel 4 di bawah ini:

\section{Tabel 4}

\section{Karakteristik Responden Berdasarkan Jenis Kelamin}

\begin{tabular}{|c|c|c|c|}
\hline \multirow{2}{*}{ No } & \multirow{2}{*}{ Jenis Kelamin } & \multicolumn{2}{|c|}{ Jumlah } \\
\cline { 3 - 4 } & & Frekuensi & Persentase \\
\hline 1 & Laki-Laki & 12 & 40 \\
\hline 2 & Perempuan & 18 & 60 \\
\hline & Jumlah & $\mathbf{3 0}$ & $\mathbf{1 0 0 \%}$ \\
\hline
\end{tabular}

Sumber: Data Primer diolah dengan SPSS 23 (2019) 
Berdasarkan tabel 4 diatas memperlihatkan karakteristik responden berdasarkan jenis kelamin. Dari data diatas dapat diketahui bahwa yang paling banyak responden dengan jenis kelamin perempuan yaitu 18 orang atau $60 \%$ dan selebihnya diisi oleh laki-laki sebanyak 12 orang atau $40 \%$. Hal ini dikarenakan staf keuangan lebih banyak perempuan dikarenakan perempuan lebih teliti, cekatan dan agresif dalam hal keuangan terutama untuk kebutuhan kantor di setiap Perusahaan Dagang Di Kota Padang.

\section{Karakteristik Responden Berdasarkan Pendidikan}

Berdasarkan proses tabulasi data yang telah dilakukan dapat diklasifikasikan pendidikan responden yang berpatisipasi di dalam penelitian, seperti yang terlihat pada tabel 5 di bawah ini:

\section{Tabel 5}

Karakteristik Responden Berdasarkan Pendidikan

\begin{tabular}{|c|c|c|c|}
\hline \multirow{2}{*}{ No } & \multirow{2}{*}{ Pendidikan } & \multicolumn{2}{|c|}{ Jumlah } \\
\cline { 3 - 4 } & & Frekuensi & Persentase \\
\hline 1 & SMA & 5 & 17 \\
\hline 2 & D3 & 15 & 50 \\
\hline 3 & S1 & 10 & 33 \\
\hline \multicolumn{2}{|c|}{ Jumlah } & $\mathbf{3 0}$ & $\mathbf{1 0 0}$ \\
\hline
\end{tabular}

Sumber: Data Primer diolah dengan SPSS 23 (2019)

Pada tabel terlihat bahwa pada umumnya responden yang berpatisipasi di dalam penelitian ini memiliki pendidikan D3 adalah 15 orang (50\%), untuk pendidikan SMA adalah 5 orang (17\%), dan yang memiliki pendidikan S1 berjumlah 10 orang (33\%). Dilihat dari tabel yang paling dominan adalah yang memiliki pendidikan D3 yang berjumlah 15 orang (50\%). 


\section{Karakteristik Responden Berdasarkan Lama Bekerja}

Berdasarkan proses tabulasi data yang telah dilakukan dapat diklasifikasikan lama bekerja responden yang berpatisipasi di dalam penelitian, seperti yang terlihat pada tabel 6 di bawah ini:

\section{Tabel 6}

Karakteristik Responden Berdasarkan Lama Jabatan

\begin{tabular}{|c|c|c|c|}
\hline \multirow{2}{*}{ No } & \multirow{2}{*}{ Lama Jabatan } & \multicolumn{2}{|c|}{ Jumlah } \\
\cline { 3 - 4 } & & Frekuensi & Persentase \\
\hline 1 & $<5$ Tahun & 8 & 27 \\
\hline 2 & 5-10 Tahun & 22 & 73 \\
\hline & Jumlah & $\mathbf{3 0}$ & $\mathbf{1 0 0}$ \\
\hline
\end{tabular}

Sumber: Data Primer diolah dengan SPSS 23 (2019)

Pada tabel diatas terlihat bahwa pada umumnya responden yang berpatisipasi di dalam penelitian ini dengan lama jabatan $<5$ tahun adalah 8 orang (27\%), dan untuk lama jabatan 5 - 10 tahun berjumlah 22 orang (73\%). Dilihat dari tabel, lama jabatan yang sedang dijalani diatas yang paling dominan adalah 5-10 tahun yang berjumlah 22 orang $(73 \%)$.

\section{Karakteristik Responden Berdasarkan Pendapatan}

Berdasarkan proses tabulasi data yang telah dilakukan dapat diklasifikasikan pendapatan responden yang berpatisipasi di dalam penelitian, seperti yang terlihat pada tabel 7 di bawah ini:

\section{Tabel 7}

Karakteristik Responden Berdasarkan Pendapatan

\begin{tabular}{|c|c|c|c|}
\hline \multirow{2}{*}{ No } & \multirow{2}{*}{ Pendapatan } & \multicolumn{2}{|c|}{ Jumlah } \\
\cline { 3 - 4 } & & Frekuensi & Persentase \\
\hline 1 & $<2.000 .000$ & 5 & 17 \\
\hline 2 & $2.000 .000-5.000 .000$ & 15 & 50 \\
\hline
\end{tabular}




\begin{tabular}{|c|c|c|c|}
\hline 3 & $>5.000 .000$ & 10 & 33 \\
\hline \multicolumn{2}{|c|}{ Jumlah } & $\mathbf{3 0}$ & $\mathbf{1 0 0}$ \\
\hline
\end{tabular}

\section{Sumber: Data Primer diolah dengan SPSS 23 (2019)}

Pada tabel 7 terlihat bahwa pada umumnya responden yang berpatisipasi di dalam penelitian ini memiliki pendapatan2.000.000 - 5.000.000 adalah 15 orang (50\%), untuk pendapatan $<2.000 .000$ adalah 5 orang (17\%), dan yang memiliki pendapatan > 5.000.000 berjumlah 10 orang (33\%). Dilihat dari tabel yang paling dominan adalah yang memiliki pendapatan2.000.000 - 5.000.000 yang berjumlah 15 orang $(50 \%)$.

\section{HASIL PENGUJIAN INSTRUMEN}

pengukuran dan pengujian ini, dilakukan berdasarkan pada data kuesioner yang telah kita dapat setelah penyebaran kuesioner tersebut. Data merupakan gambaran suatu objek atau variabel yang akan diteliti dan juga memegang peranan penting dalam suatu penelitian, sebelum data diolah instrumen ini diuji terlebih dahulu dengan menggunakan uji validitas dan reliabilitas agar memperoleh hasil yang bisa dipertanggung jawabkan

Uji validitas dilakukan untuk mengetahui seberapa baik suatu instrument dapat mengukur suatu konsep yang seharusnya diukur dan mengetahui pernyataan-pernyataan dalam suatu instument adalah valid. Uji ini dilakukan dengan menggunakan analisis faktor (factor analysis) yaitu factor loading untuk memastikan masing- 
masing pernyataan terklarifikasi pada setiap variabel yang ditentukan.

Kuesioner juga dikatakan valid jika pernyataan pada kuesioner mampu untuk mengungkapkan sesuatu yang akan diukur oleh kuesioner tersebut, Uji validitas dalam penelitian ini yaitu dengan melakukan KMO and Bartlett's Test, untuk mengetahui bahwa suatu indikator yang digunakan dapat mengkonfirmasi sebuah konstruk yang dimana nilai Kaiser-mayer-olkin test berkisar dari $0-1$, semakin mendekati 1 , berarti semakin bagus. Nilai yang dapat diterima adalah diatas 0,5. Nilai Bartlett's test yang dapat diterima adalah jika signifikansi dibawah 0,05 dan yang paling bagus jika dibawah 0,01. Hasil uji validitas terhadap kuesioner, pengukur variabel penelitian disajikan dalam tabel 8 di bawah ini:

Tabel 8 Hasil Uji Validitas

\begin{tabular}{|l|c|c|c|}
\hline \multicolumn{1}{|c|}{ Variabel } & Batas KMO & $\begin{array}{c}\text { KMO and } \\
\text { Bartlett's }\end{array}$ & Keputusan \\
\hline $\begin{array}{l}\text { Persepsi Akuntan } \\
\text { Manajemen (X) }\end{array}$ & 0,050 & 0,757 & Valid \\
\hline $\begin{array}{l}\text { Penerapan Tax } \\
\text { Planing (Y) }\end{array}$ & 0,050 & 0,757 & Valid \\
\hline
\end{tabular}

\section{Sumber: Data Primer diolah dengan SPSS 23 (2019)}

Berdasarkan tabel 8 tingkat konsistensi dan akurasi menunjukkan cukup baik. Berdasarkan hasil perhitungan yang ditunjukkan pada tabel diatas nilai Kaiser-Meyer-Olkin Measure Of Sampling Adequacy (Kaiser's MSA) sebesar 0,757 > 0,50 sehingga 
dapat disimpulkan bahwa butir-butir pernyataan pada variabel $\mathrm{X}$ (Persepsi Akuntan Manajemen) dinyatakan valid dan pada variabel Y, nilai Kaiser-Meyer-Olkin Measure Of Sampling Adequacy (Kaiser's MSA) sebesar 0,757 > 0,50 dan dapat disimpulkan juga bahwa butir-butir pernyataan pada variabel Y (Penerapan Tax Planning) dinyatakan valid.

Hasil Uji Reliabilitas bertujuan untuk mengetahui sejauh mana pengukuran yang telah dilakukan dalam penelitian ini dapat dipercaya dan dapat diandalkan. Uji reliabilitas ini diukur dengan

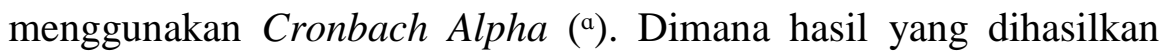
lebih besar dari 0,60, maka instrumen yang digunakan dapat dikatakan reliabel. Adapun hasil uji reliabilitas dalam penelitian ini dapat dilihat dalam tabel 9 di bawah ini:

Tabel 9

Hasil Uji Reliabilitas

\begin{tabular}{|l|c|c|c|}
\hline \multicolumn{1}{|c|}{ Variabel } & $\begin{array}{c}\text { Batasan } \\
\text { Nilai }\end{array}$ & $\begin{array}{c}\text { Cronbach's } \\
\text { Alpha }\end{array}$ & Keputusan \\
\hline $\begin{array}{l}\text { Persepsi } \\
\text { Akuntan } \\
\text { Manajemen (X) }\end{array}$ & 0,60 & 0,900 & Reliabel \\
\hline $\begin{array}{l}\text { Penerapan Tax } \\
\text { Planing (Y) }\end{array}$ & 0,60 & 0,930 & Reliabel \\
\hline
\end{tabular}

\section{Sumber: Data Primer diolah dengan SPSS 23 (2019)}

Berdasarkan pada tabel 9 di atas, hasil pengujian menemukan untuk seluruh variabel mempunyai cronbach's Alpha yang cukup besar yaitu berada di atas 0,60, sehingga dapat dikatakan semua konsep pengukuran masing-masing variabel dari kuesioner adalah 
reliabel sehingga selanjutnya item-item pada masing-masing variabel tersebut dapat digunakan sebagai alat ukur lebih lanjut.

\section{Pengujian Hipotesis}

\section{Tabel 10}

Hasil Pengujian Koefisien Determinasi (R-square)

\begin{tabular}{|l|c|}
\hline \multicolumn{1}{|c|}{ Keterangan } & Koefisien \\
\hline$R$-Square & 0,620 \\
\hline Adjust $R$-Square & 0,607 \\
\hline
\end{tabular}

Sumber: Data Primer diolah dengan SPSS 23 (2019)

Berdasarkan tabel 10 hasil pengujian koefisien determinasi diperoleh nilai $R$-square sebesar 0,620 hasil yang diperoleh tersebut mengisyaratkan bahwa variabel persepsi Akuntan Manajemen variasi kontribusi dalam mempengaruhi penerapan tax planning sebesar $62 \%$ sedangkan sisanya $38 \%$ lagi dijelaskan oleh variabel lain yang belum digunakan didalam penelitian saat ini.

Berdasarkan hasil pengujian t-statistik yang telah dilakukan diperoleh ringkasan hasil terlihat pada tabel 4dibawah ini:

\section{Tabel 4}

\section{Hasil Pengujian Hipotesis}

\begin{tabular}{|l|c|c|c|c|}
\hline \multicolumn{1}{|c|}{$\begin{array}{c}\text { Variabel } \\
\text { Penelitian }\end{array}$} & Koefisien & Signifikansi & Alpha & Kesimpulan \\
\hline C & 16,164 & & & \\
\hline $\begin{array}{l}\text { Persepsi } \\
\text { Akuntan } \\
\text { Manajemen }\end{array}$ & 0,669 & & 0,05 & H1 Diterima \\
\hline
\end{tabular}


Berdasarkan tabel 4 dapat diturunkan persamaan model analisis regresi panel adalah

$$
P T P=16,164+0,669 P A K_{X 1}
$$

Pada model regresi sederhana terlihat nilai konstanta yang dihasilkan adalah sebesar 16,164 nilai yang diperoleh tersebut mengisyaratkan bahwa jika diasumsikan tidak terjadi perubahan (peningkatan atau penurunan) variabel Persepsi akuntan manajemen maka nilai dari variabel Penerapan Tax Planning adalah sebesar 16,164 .

Model persamaan regresi sederhana juga terlihat bahwa variabel Persepsi Akuntan Manajemen memiliki nilai koefisien regresi bertanda positif sebesar 0,669. Nilai koefisien yang diperoleh menunjukkan bahwa ketika diasumsikan terjadi peningkatan Persepsi Akuntan Manajemen pada perusahaan sebesar 1 satuan akan meningkatkan penerapan tax planning sebesar 0,669 dengan asumsi faktor lain selain persepsi akuntan manajemen dianggap tetap atau konstan.

\section{Pengujian Hipotesis Persepsi Akuntan Manajemen terhadap Penerapan Tax Planning}

Berdasarkan hasil pengujian hipotesis pertama dengan menggunakan variabel Persepsi Akuntan Manajemen diperoleh nilai signifikan sebesar 0,000. Di dalam tahapan pengujian digunakan tingkat kesalahan sebesar 0,05. Hasil yang diperoleh menunjukkan bahwa nilai signifikansi sebesar $0,000 \geq$ alpha 0,05 maka keputusannya 
adalah Ho diterima dan Ha ditolak sehingga dapat disimpulkan bahwa persepsi akuntan manajemen berpengaruh positif terhadap Penerapan Tax Planning.

\section{PEMBAHASAN}

\section{Pengaruh Persepsi Akuntan Manajemen terhadap Penerapan}

\section{Tax Planning}

Berdasarkan hasil pengujian dapat diinterpretasikan bahwa Persepsi Akuntan Manajemen Berpengaruh positif dan signifikan terhadap penerapan tax planning pada perusahaan distributor makanan di Kota Padang. Hasil ini menunjukkan bahwa penguasaan akuntan manajemen pada perusahaan distributor makanan dalam mengambil keputusan memberikan informasi dan kebijakan dalam menerapkan tax planning pada perusahaan sudah baik, hasil ini terbukti di berdasarkan survey observasi dilapangan laba perusahaan pada distributor makanan cukup besar, dan perusahaan mampu menimalisir pembayaran pajak kepemerintah, dengan perhitungan dan metode yang cocok digunakan pada perusahaan. Seorang manajer bertanggungjawab penuh terhadap perusahaan dalam memberikan kebijakan dan keputusan dalam menerapkan tax planning. Pembayaran pajak penghasilan perusahaan akan meningkat apabila laba perusahaan mengalami peningkatan, otomatis akan menurunkan laba perusahaan. Menimalisir Pembayaran pajak sangat bermanfaat bagi perusahaan menerapkan tax planning pada perusahaan, dan memberikan kontribusi yang 
besar pada perusahaan. Perusahaan Distributor Makanan di Kota Padang cukup besar, dan maju, makanya akuntan manajer berusaha bagaimana caranya dalam menimalisir beban penghasilan perusahaan berkurang. Penerapan tax Planning pada perusahaan distributor makanan di Kota Padang pada umumnya sudah baik dan sudah sesuai dengan ketentuan perundang-undangan ketetapan pajak perusahaan.

Penelitian yang dilakukan (Tanjung \& Tjondro, 2013), (Muhammadinah, 2015), (Indrawati \& Budiwitaksono, 2017) sesuai persepsi akuntan manajemen berpengaruh terhadap Tax Planning . Semakin baik Seorang akuntan manajemen dalam memberikan pandangan dan keputusan maka akan semakin baik penerapan tax planning. Penggunaan informasi dan kebijakan dalam menentukan metode tax planning didalam perusahaan akan memberikan penghematan pajak didalam perusahaan. Penerapan tax planning didalam perusahaan memberikan effisiensi pembayaran beban pajak didalam perusahaan. Penghematan dalam membayar pajak ditakan effektif dan effisien apabila menggunakan tax planning menggunakan metode yang tepat dan sesuai dengan undang-undang perpajakan yang berlaku. Penguasaan seorang manajemen dalam memahami peraturan dan perudang-undangan perpajakan yang berlaku maka pihak manajemen perusahaan dapat menjalankan kebijakan tax planning yang dibuat tanpa melanggar peraturan perudang-undangan perpajakan. 


\section{PENUTUP}

Berdasarkan hasil pengujian yang telah dilakukan dapat disimpulkan bahwa Persepsi Akuntan Manajemen berpengaruh terhadap penerapan tax planning pada perusahaan distributor di Kota Padang. penguasaan akuntan manajemen pada perusahaan distributor makanan dalam mengambil keputusan memberikan informasi dan kebijakan dalam menerapkan tax planning pada perusahaan sudah baik.

Saran yang dapat diberikan untuk penelitian selanjutnya dapat menambah variabel yang dapat mempengaruhi penerapan tax planning, dan objek sampel yang digunakan dapat bervariasi agar dapat menunjukkan perbedaan hasil penelitian yang semakin baik.

\section{DAFTAR RUJUKAN}

Annisa, R. R., \& Handayani, B. D. Analisa Faktor Yang Memotivasi Manajemen Perusahaan Melakukan Tax Planning. Accounting Analysis Journal, 4(1), 2015, 1-11.

Ghazali, I. Analisasis Multivariat DenganPogram SPSS (dua). Semarang: Universitas diponegoro, 2013.

Gibson, J. L., Ivancevich, J. M., Jr.Donnelly, J. H., \& Konopaske, R. Organizations: Behavior, Structure, Processes (Edisi 14). McGraw-Hill, 2011.

Harahap, A. J. Kebijakan Tax Planning Untuk Menyesuaikan Pajak Penghasilan Pada PT . Sofara Cipta Kirana. Skripsi Universitas Sumatera Utara, 2009. 
Indrawati, \& Budiwitaksono, G. S. Studi Faktor-Faktor Pemotivasi Manajemen Melakukan Tax Planning. Jurnal Akuntansi, 19(3), 2017, 370. https://doi.org/10.24912/ja.v19i3.86

Mardiasmo. Perpajakan Edisi Revisi. Yogyakrta: Andi, 2009.

Martadi, I. F., \& Suranta, S. Persepsi Akuntan Manajemen, Mahasiswa Akutansi, dan Karyawan Bagian Akutansi dipandang dari Segi Gender Terhadap Etika Bisnis dan Etika Profesi (Studi di Wilayah Surakarta), 2006. Simposium Nasional Akuntansi ( ..., 5. Retrieved from http://digilib.mercubuana.ac.id/manager/file_artikel_abstrak/ Isi_Artikel_885466244943.pdf

Muhammadinah. Penerapan Tax Planning Dalam Upaya Meningkatkan Efisiensi Pembayaran Beban Pajak Pada Cv. Iqbal Perkasa. I-Finance, 1(1), 2015 21-34. Retrieved from http://jurnal.radenfatah.ac.id/index.php/I-

Finance/article/view/307

Natakharisma, V., \& Sumadi, I. K. Analisis Tax Planning Dalam Meningkatkan Optimalisasi Pembayaran Pajak Penghasilan Pada PT . Chidehafu. E-Jurnal Akuntansi Universitas Udayana, 2, $2014 \quad 324-339 . \quad$ Retrieved from https://ojs.unud.ac.id/index.php/Akuntansi/article/view/8196/ 7272

Robbins, S. P., \& Judge, T. A. Perilaku Organisasi (Organizational Behaviour) (12th ed.). Jakarta: Salemba Empat, 2008.

Rori, H. Analisis Penerapan Tax Planning Atas Pajak Penghasilan 
Badan. Jurnal EMBA, 1(3), 2013. 410-418.

Rusmanto, Mentayani, I., \& Yani, S. N. Persepsi Akuntan dan Mahasiswa Jurusan Akuntansi Terhadap Kode Etik Ikatan Akuntan Indonesia. JAFFA, 2(2), 2014,115-126.

Sucipto. Penerapan Akuntansi Manajemen Dalam Mengambil Keputusan. Jurnal Universitas Sumatera Utara, 2004, 1-8.

Sugiyono. Metode Penelitian Bisnis. Bandung: Alfabeta, 2017.

Tanjung, S., \& Tjondro, E. Pengaruh kebijakan perpajakan, peraturan perpajakan, sanksi administrasi dan pemeriksaan pajak, presepsi wajib pajak terhadap perencanaan pajak wajib pajak orang pribadi yang merupakan klien dari kantor konsultan pajak x. Tax \& Accounting Review, 1(1), 2013, $146-151$.

Waluyo. perpajakan indonesia (12th ed.). Jakarta: Salemba Empat, 2017.

Yenni Mangoting. Tax Planning: Sebuah Pengantar Sebagai Alternatif Meminimalkan Pajak. Jurnal Akuntansi Dan Keuangan, 1(1), 1999, 43-53. 